\title{
Het concern en het ontslagrecht: de Hoge Raad eist maatwerk
}

\author{
HR 18 januari 2019, ECLI:NL:HR:2019:64 (Shell)
}

\author{
M.A.N. van Schadewijk
}

\section{$1 \quad$ Inleiding}

Met de invoering van de Wet werk en zekerheid (Wwz) toonde de wetgever oog voor concernverhoudingen in het arbeidsrecht, waaronder het ontslagrecht. De met de Wwz ingevoerde Ontslagregeling bevat meerdere verwijzingen naar het concern. ${ }^{1}$ De meest besproken verwijzing is die ten aanzien van het herplaatsingsvereiste. $^{2}$ Op grond van artikel 7:669 lid 1 van het Burgerlijk Wetboek (BW) kan de werkgever de arbeidsovereenkomst opzeggen als daar een redelijke grond voor is en herplaatsing in een andere passende functie binnen een redelijke termijn niet mogelijk is of niet in de rede ligt. Artikel 9 Ontslagregeling concretiseert het herplaatsingsvereiste. Artikel 9 lid 2 bepaalt:

'Indien de onderneming van de werkgever deel uitmaakt van een groep, worden bij de beoordeling of een passende functie beschikbaar is mede arbeidsplaatsen in andere tot deze groep behorende ondernemingen betrokken.'

De poging van de wetgever om de betekenis van het concern bij herplaatsing te codificeren is te prijzen. Artikel 9 lid 2 Ontslagregeling leidt echter tot een stroom aan rechtsvragen die de wetgever - in de Ontslagregeling of de toelichting daarop $^{3}$ - noch het Uitvoeringsinstituut Werknemersverzekeringen (UWV) - in de Uitvoeringsregels Ontslag om bedrijfseconomische redenen (hierna: Uitvoe-

1 Met het begrip 'concern' doel ik op de groep in de zin van artikel 2:24b BW en artikel 1 onder e Ontslagregeling.

2 Publicaties die geheel of voor een aanzienlijk deel zijn gewijd aan concernbrede herplaatsing onder de Wwz zijn F.G. Laagland \& I. Lintsen, Werkgeverschap in concernverhoudingen, TRA 2016/13; L.B. de Graaf, Herplaatsing: waar is de redelijkheid gebleven?, TRA 2016/82; R. Olivier \& J.P. Wiewel, Herplaatsing binnen de groep, TAP 2017/67; R. Beltzer \& S. Schmeetz, Herplaatsing binnen het concern, TvO 2017/2; L.G. Verburg, De curator en het concern: arbeidsrechtelijke perspectieven, in: E. Verwey (red.), De curator en het concern, Deventer: Kluwer 2017; T.J. van Frankenhuijsen, Concern-brede herplaatsing: wat is de laatste stand van zaken?, ArbeidsRecht 2018/5; P. Kruit \& J. Sap, De herplaatsingsplicht in de praktijk, TvO 2018/2; I.M. Veerkamp, De herplaatsing binnen het concern, Weert: Celsus Juridische Uitgeverij 2018.

Stcrt. 2015, nr. 12685. 
ringsregels UWV $)^{4}$ - sluitend beantwoordt. In zijn beschikking van 18 januari 2019 over het ontslag van een expat van het Shell-concern verschaft de Hoge Raad enige duidelijkheid over het juridische karakter en de reikwijdte van het herplaatsingsvereiste. De Hoge Raad beantwoordt daarnaast de vraag hoe het afvloeiingsbeleid van het Shell-concern zich verhoudt tot het grondenstelsel van artikel 7:669 BW. In deze annotatie zet ik de beschikking uiteen en onderwerp ik beide onderdelen van de beschikking aan een nadere analyse. Het commentaar spitst zich toe op de betekenis van de beschikking voor de plaats van het (internationale) concern in het ontslagrecht, specifiek de Ontslagregeling. Ik sluit af met enkele bespiegelingen over de status quo van het concern in het ontslagrecht naar aanleiding van de beschikking.

\section{Feiten en procesverloop in feitelijke instanties}

De beschikking van de Hoge Raad draait grotendeels om de arbeidsvoorwaardenregeling van de expats van het Shell-concern, de Long Term International Assignment Policies (LTIA-regeling). Het is daarom nodig om wat uitgebreider stil te staan bij deze regeling. Op grond van de LTIA-regeling worden werknemers vanuit hun base country (het land waar zij zijn gerekruteerd) uitgezonden naar een host country (het tijdelijke werkland) om voor een bepaalde periode werkzaamheden te verrichten. Het Shell-concern verwacht mobiliteit van zijn expats en compenseert hen daarvoor financieel. ${ }^{5}$ Bij uitzending wordt de arbeidsovereenkomst van de expat in de base country beëindigd en sluit de expat voor de duur van de uitzending een arbeidsovereenkomst met een Shell-vennootschap in de host country. Voor het einde van de uitzendtermijn kan de expat deelnemen aan het Managed Open Resourcing-systeem (MOR-systeem). Het MOR-systeem voorziet in vier collectieve interne sollicitatierondes per jaar via een wereldwijd online platform waarop alle vacatures binnen het Shell-concern kenbaar worden gemaakt. Expats kunnen op het platform hun cv plaatsen en naar nieuwe functies zoeken. Indien herplaatsing binnen drie maanden na het einde van de uitzendtermijn niet lukt, dan krijgt de expat een arbeidsovereenkomst aangeboden in zijn base country. Dit 'papieren' dienstverband heeft geen ander doel dan de werknemer een betrekking te geven waarin hij hetzij een nieuwe functie vindt, hetzij overtollig raakt. Voor expats met Nederland als base country gold in de periode van 1 januari 2012 tot 30 juni 2016 de Overtolligheidsregeling 2012-2016 (LOR 2012). Op grond van de LOR 2012 krijgt een werknemer na terugkeer naar Nederland drie maanden de tijd om een andere functie te vinden. Daarna wordt hij aangemerkt als overtollig. Bij overtolligheid kan een werknemer kiezen tussen een periode van begeleid zoeken en een vergoeding voor versneld vertrek. Indien het begeleid zoeken op niets uitloopt, dan voorziet de LOR 2012 in beëindiging van de arbeidsovereenkomst onder toekenning van een beëindigingsvergoeding. Een

$4 \quad$ Meest recente versie van augustus 2018.

5 Zie in meer detail r.o. 1.3.2 van de bestreden beschikking: Hof Den Haag 19 september 2017, ECLI:NL:GHDHA:2017:2654, JIN 2018/90, m.nt. Mees. 
overtollig verklaarde werknemer die een passende functie weigert, verliest aanspraak op de beëindigingsvergoeding.

Deze laatste situatie deed zich voor in de zaak die leidde tot de beschikking van de Hoge Raad. Werknemer trad in 1975 in dienst van Shell Tankers B.V. in base country Nederland. Hij was vervolgens als expat achtereenvolgens in dienst van verschillende Shell-vennootschappen. Werknemer werkte laatstelijk als expat in dienst van Shell Gabon in de functie van Head of Marine Services. Wegens het niet kunnen verlengen van de werkvergunning in Gabon ging werknemer vanaf februari 2015 via het MOR-systeem op zoek naar een nieuwe functie. Aangezien hij hier niet tijdig in slaagde, werd per 26 augustus 2015 de arbeidsovereenkomst met Shell Gabon beëindigd en trad werknemer conform de LTIA-regeling voor onbepaalde tijd in dienst bij Shell International Exploration and Production B.V. (hierna: SIEP) in base country Nederland. Op 16 oktober 2015 bood SIEP werknemer de functie van Maritime Assurance Assessor (MAA) te Rotterdam aan. Werknemer weigerde het aanbod. Hij vond de functie niet passend en onverenigbaar met de persoonlijke omstandigheid dat zijn gezin in de Filipijnen woonde. Toen het hem niet lukte om een andere functie te bemachtigen, probeerde hij op 22 januari 2016 alsnog de inmiddels vergeven functie van MAA te aanvaarden. Werknemer heeft uiteindelijk vanaf februari 2015 in vier MOR-rondes zonder succes gesolliciteerd op vijftien interne functies.

SIEP stelt een succesvol ontbindingsverzoek in bij de Kantonrechter Rotterdam op de h-grond van artikel 7:669 lid 3 BW. In hoger beroep stelt werknemer dat de h-grond niet van toepassing is en dat SIEP niet voldaan heeft aan haar concernbrede herplaatsingsplicht. Het Gerechtshof Den Haag verwerpt het hoger beroep. ${ }^{6}$ Het hof overweegt dat de mobiele en tijdelijke inzetbaarheid in het Shellconcern inherent is aan de hoedanigheid van expat. Daarom vallen de toets van de redelijke grond en die van de herplaatsing in dit geval samen. SIEP heeft voldoende inspanningen verricht om werknemer elders in het concern te herplaatsen. Het hof verwerpt de stelling van werknemer dat hij bij andere concernonderdelen voorrang zou genieten boven externe sollicitanten en flexibele arbeidskrachten (de zogenoemde 'plaatsmakers'7). Het bepaalde in artikel 7:669 lid 1 BW, dat herplaatsing 'in de rede' moet liggen, vergt een individuele redelijkheidstoets. Op grond van deze redelijkheidstoets komt werknemer niet de gestelde voorrang toe. Het valt volgens het hof, gelet op de juridische zelfstandigheid en de ondernemersvrijheid van de afzonderlijke concernonderdelen, namelijk niet in te zien hoe SIEP de andere concernonderdelen zou kunnen bewegen werknemer met voorrang te plaatsen. 


\section{Cassatiemiddel en conclusie plaatsvervangend P-G Langemeijer}

In zijn uitvoerige conclusie concludeert plaatsvervangend $\mathrm{P}-\mathrm{G}$ Langemeijer tot verwerping van het cassatieberoep, dat uit vier onderdelen bestaat. ${ }^{8}$ Cassatieonderdeel 1 komt op tegen het oordeel van het hof dat sprake is van een (voldragen) h-grond. Volgens werknemer behoren de door SIEP aan het ontbindingsverzoek ten grondslag gelegde feiten en omstandigheden tot het domein van de a-grond, de bedrijfseconomische reden. Uit de wetsgeschiedenis ontwaart de plaatsvervangend P-G dat de h-grond bedoeld is voor situaties die niet zijn terug te voeren naar de andere in artikel 7:669 lid 3 BW opgesomde ontslaggronden. Hij gaat mee met de opvatting in de literatuur en de rechtspraak dat de h-grond zich leent voor de arbeidsovereenkomst die een 'lege huls' is wegens het feitelijk of rechtens onmogelijk zijn geworden van het verrichten van de bedongen arbeid. Hij acht ontbinding op de h-grond van een arbeidsovereenkomst die een lege huls is toelaatbaar, maar alleen als de omstandigheden die de arbeidsovereenkomst van haar inhoud hebben ontdaan voldoende verschillen van de in artikel 7:669 lid 3 onder a tot en met $\mathrm{g}$ BW genoemde omstandigheden. Hij erkent dat er een zekere overlap kan bestaan tussen de onder h en onder a tot en met g genoemde omstandigheden, en acht doorslaggevend of een werkgever de h-grond niet gebruikt om een andere, onvoldragen ontslaggrond te repareren. Hij concludeert vervolgens dat van reparatie van een onvoldragen a-grond geen sprake is. Anders dan werknemer is hij niet van mening dat de werkelijke reden van het ontbindingsverzoek is dat SIEP geen werk voor werknemer beschikbaar heeft (wat tot het domein van de a-grond zou behoren). Ter onderbouwing verwijst de plaatsvervangend P-G naar de vijftien onsuccesvolle sollicitaties van werknemer binnen het concern, de door werknemer geweigerde functie van MAA en het feit dat SIEP werknemer nog heeft gewezen op andere vacatures binnen het concern. De plaatsvervangend P-G benoemt nog wel dat er binnen het concern verslechterde bedrijfseconomische omstandigheden waren die zouden kunnen nopen tot ontslag, maar concludeert dat deze omstandigheden slechts indirect verband houden met de reden voor ontslag, de niet-herplaatsbaarheid van werknemer. Hij verwerpt voorts de rechtsklacht tegen het oordeel van het hof dat de toetsing van de redelijke grond en de herplaatsing in dit geval samenvallen. Het hof miskent volgens de plaatsvervangend P-G niet dat het twee zelfstandige vereisten betreft. Het hof concludeert slechts dat de twee vereisten voor dit geval op hetzelfde neerkomen. Dat oordeel acht de plaatsvervangend P-G niet in strijd met het recht.

De andere drie cassatieonderdelen hebben betrekking op de mogelijkheden tot herplaatsing van werknemer in het Shell-concern. Onderdeel 2 heeft betrekking op het juridische karakter van het herplaatsingsvereiste. Het onderdeel bevat een rechtsklacht tegen het oordeel van het hof dat het herplaatsingsvereiste (2.1) een individuele redelijkheidstoets vergt en (2.2) niet de door werknemer gestelde afdwingbare voorrang omvat. Op basis van de wetsgeschiedenis van de Wwz vat de plaatsvervangend P-G het herplaatsingsvereiste als volgt samen. De werkgever 
heeft de plicht de herplaatsingsmogelijkheden te stellen en te onderzoeken. ${ }^{9} \mathrm{Zijn}$ er herplaatsingsmogelijkheden aanwezig, dan is de vervolgvraag of het in de rede ligt dat de werkgever die herplaatsingsmogelijkheden daadwerkelijk benut. Onder verwijzing naar de Bossers \& Cnossen-beschikking van de Hoge Raad ${ }^{10}$ concludeert de plaatsvervangend P-G dat de term 'in de rede' een redelijkheidsventiel met zich brengt. De rechter kan, op grond van een nadere weging van de omstandigheden van het geval, tot het oordeel komen dat herplaatsing, hoewel mogelijk, niet in de rede ligt. Vanwege de ondernemersvrijheid komt de werkgever hierin enige beoordelingsruimte toe. Voor het concern brengt een en ander met zich dat het ontbreken van zeggenschap van de werkgever over de andere concernonderdelen en de vrijheid van de andere concernonderdelen om een eigen personeelsbeleid te voeren twee gezichtspunten zijn die de rechter moet meewegen in zijn oordeel of herplaatsing met voorrang elders in het concern in de rede ligt. In het licht van de overige door het hof vastgestelde feiten en omstandigheden (het bestaan van de LTIA-regeling en het geavanceerde MOR-systeem, de reële kansen van werknemer om zich te laten herplaatsen en het weigeren van de MAA-functie door werknemer) acht de plaatsvervangend P-G het oordeel van het hof, dat herplaatsing met voorrang elders binnen het Shell-concern niet in de rede ligt, geen blijk geven van een onjuiste rechtsopvatting.

In het verlengde van onderdeel 2 komt onderdeel 3 erop neer dat het hof te lichte eisen heeft gesteld aan de van SIEP te vergen inspanningen tot herplaatsing. Het onderdeel faalt, aangezien het volgens de plaatsvervangend $\mathrm{P}-\mathrm{G}$ uitgaat van een onjuiste lezing van de overwegingen van het hof. Onderdeel 4 klaagt dat de werkgeefster tekort is geschoten omdat SIEP aan de werknemer geen lijst heeft verstrekt van de plaatsmakersfuncties bij de andere concernonderdelen. Het onderdeel is meer in het bijzonder gericht tegen de overweging van het hof dat het hierbij gaat om 'kwesties die typisch de Nederlandse arbeidsmarkt betreffen'. Volgens het onderdeel miskent het hof dat artikel 9 lid 1 onder b Ontslagregeling geen onderscheid maakt tussen in Nederland en in het buitenland gelokaliseerde plaatsmakersfuncties. Volgens de plaatsvervangend P-G bedoelt het hof te zeggen dat het bij die arbeidsplaatsen onder andere gaat om kwesties die typisch de Nederlandse arbeidsmarkt betreffen, zoals arbeidsplaatsen van bijna AOWgerechtigden en zzp'ers. Het hof overweegt slechts dat de Ontslagregeling wat betreft die typisch Nederlandse kwesties niet rechtstreeks kan worden toegepast op arbeidsplaatsen in het buitenland, aangezien het buitenlandse arbeidsrecht die

9 Tenzij, zo overweegt de plaatsvervangend P-G, sprake is van een van de in artikel 7:669 BW genoemde uitzonderingen (lid 1: bij verwijtbaar handelen (e-grond) ligt herplaatsing per definitie niet in de rede; lid 2: herplaatsing is niet vereist indien de werknemer een geestelijk ambt bekleedt).

10 HR 16 februari 2018, ECLI:NL:HR:2018:220, NJ 2018/394, m.nt. Verhulp, TRA 2018/41, m.nt. Buijs, JIN 2018/108, m.nt. Van Puffelen \& Van der Velden, JAR 2018/73, m.nt. De Graaf, AR Updates 2018-0216, m.nt. Laagland (Bossers \& Cnossen). De Hoge Raad overwoog dat herplaatsing niet in de rede lag in de situatie dat de werkgever reeds diverse aanpassingen in het werk had getroffen en de arbeidsrelatie duurzaam verstoord was geraakt (r.o. 3.5.2). Onduidelijk was of de Hoge Raad hiermee de redelijkheidsnorm had omarmd (A.R. Houweling (red.) e.a., C.J. Loonstra \& W.A. Zondag, Arbeidsrechtelijke Themata II, Den Haag: Boom Juridisch 2018, p. 58). 
arbeidsplaatsen niet kent. Dat oordeel is volgens de plaatsvervangend P-G onjuist noch onbegrijpelijk.

\section{De beschikking van de Hoge Raad}

De Hoge Raad komt in zijn bondige beschikking tot hetzelfde resultaat als de plaatsvervangend P-G. Van een a-grond is geen sprake, nu onweersproken is dat bij SIEP geen arbeidsplaatsen zijn vervallen. Er is evenmin sprake van verhulling van een a-grond. Daartoe overweegt de Hoge Raad, onder verwijzing naar dezelfde (in cassatie onbestreden) omstandigheden als die de plaatsvervangend P$G$ noemde, dat binnen het Shell-concern in principe werk beschikbaar was voor werknemer. Er deden zich met andere woorden geen bedrijfseconomische omstandigheden voor die SIEP zouden kunnen nopen tot het laten vervallen van arbeidsplaatsen. Ook de klacht tegen het oordeel van het hof, dat de vereisten van de redelijke grond en de herplaatsing in dit geval samenvallen, faalt. Het hof heeft niet miskend dat het twee zelfstandige vereisten betreft. De h-grond is voorts een algemeen geformuleerde restcategorie. Dit betekent dat onder omstandigheden sprake kan zijn van een h-grond op de enkele grond dat herplaatsing niet in de rede ligt.

Ten aanzien van onderdeel 2.1 ontwaart de Hoge Raad uit de door de plaatsvervangend P-G uiteengezette wetsgeschiedenis dat de wetgever met het in artikel 7:669 lid 1 BW en de Ontslagregeling neergelegde herplaatsingsvereiste geen breuk heeft beoogd met het voor de invoering van de Wwz geldende recht. De Hoge Raad concludeert, net als de plaatsvervangend P-G, onder verwijzing naar zijn Bossers \& Cnossen-beschikking dat daarom moet worden aangenomen dat met het gebruik van het begrippenpaar 'niet mogelijk is of niet in de rede ligt' niet is beoogd een resultaatsverplichting tot herplaatsing in het leven te roepen, maar dat het gaat om hetgeen in de gegeven omstandigheden in redelijkheid van de werkgever kan worden gevergd. Ten aanzien van de term 'in de rede' overweegt de Hoge Raad dat deze dus niet enkel betrekking heeft op omstandigheden waardoor het vanzelfsprekend is om de werknemer niet te herplaatsen, maar ook op redelijkheidsargumenten. Daarmee wordt de werkgever een zekere beoordelingsruimte gelaten. Het onderdeel mist dus doel.

De Hoge Raad doet de overige klachten van het middel af onder verwijzing naar artikel 81 van de Wet op de rechterlijke organisatie (Wet RO). 


\section{De ruimte voor concernbeleid in het grondenstelsel van artikel 7:669 BW}

\subsection{De h-grond als escape voor concernbeleid}

Al sinds de behandeling van de Wwz in de Tweede Kamer bestaat discussie over de reikwijdte van de h-grond. ${ }^{11}$ De wetsgeschiedenis is niet eenduidig. De regering stelt dat de h-grond bedoeld is voor situaties die 'niet vallen onder' en die 'niet terug zijn te voeren naar' de overige gronden genoemd in artikel 7:669 BW, zoals detentie en illegaliteit. ${ }^{12}$ De h-grond mag niet worden gebruikt voor het repareren van andere, onvoldragen ontslaggronden. ${ }^{13}$ In de nota naar aanleiding van het verslag doet de regering de h-grond vervolgens een stuk ruimer voorkomen. Als mogelijke h-grond noemt de regering bijvoorbeeld de enigszins aan disfunctioneren (d-grond) verwante situatie dat een voetbaltrainer wordt ontslagen wegens achterblijvende resultaten, omdat in die situatie van disfunctioneren geen sprake is of hoeft te zijn. ${ }^{14}$ Uit de lagere rechtspraak lijkt te volgen dat rechters de door de wetgever gegeven bewegingsruimte aangrijpen, maar er over het algemeen voor waken dat werkgevers de h-grond gebruiken om één of meerdere andere, onvoldragen ontslaggronden te repareren. ${ }^{15}$ De Hoge Raad volgt in de Shell-beschikking eenzelfde koers. De h-grond betreft volgens de Hoge Raad een algemeen geformuleerde restcategorie die moet worden ingevuld op grond van de omstandigheden van het geval. Gebruik van de h-grond mag geen andere ontslaggrond 'verhullen'. Deze terminologie impliceert, zoals de plaatsvervangend P-G expliciet stelde, dat er wel enige verwantschap mag bestaan met de onder a tot en met g genoemde omstandigheden. Waar de grens ligt tussen verwantschap en verhulling maakt de Hoge Raad niet duidelijk. Volgens de Hoge Raad was überhaupt niet gebleken van bedrijfseconomische redenen die SIEP ertoe zouden kunnen nopen om de arbeidsplaats van werknemer te laten vervallen. Zodoende kon van een verhulde a-grond geen sprake zijn. De plaatsvervangend P-G ziet daarentegen wel verslechterde bedrijfseconomische omstandigheden en toetst of de redenen die SIEP ten grondslag legde aan het ontslag niet overwegend een bedrijfseconomische aard hebben. Zie hierna paragraaf 5.2.1.

De Hoge Raad laat zich niet uitgebreid uit over de toepassing van de h-grond op de expat met een dienstverband dat vanaf dag één een lege huls is. Dat hoefde ook niet, aangezien de Hoge Raad expliceert dat de h-grond als 'algemeen geformuleerde restcategorie' ook in deze situatie van toepassing kan zijn. De h-grond

11 Zie bijv. A.J. Swelheim, Draait de redelijke grond de ontbindingsprocedure op slot?, ArbeidsRecht 2014/51, par. 3.2; D.M.A. Bij de Vaate \& N. Hummel, De Wet werk en zekerheid: omgekeerde normalisering?, TRA 2014/64, par. 3.3; J.T. van der Kroon, M.R. van der Vos \& P.A. Meijer, De 'andere omstandigheden' van de h-grond; ruim een jaar op weg, TRA 2016/83, p. 24.

12 Kamerstukken II 2013/14, 33818, 3, p. 46 en 84; Kamerstukken II 2013/14, 33818, 7, p. 44. Dezelfde terminologie hanteert de regering in het wetsvoorstel Wet arbeidsmarkt in balans (Wab); Kamerstukken II 2018/19, 35074, 3, p. 56.

13 Kamerstukken I 2013/14, 33818, C, p. 91.

14 Kamerstukken II 2013/14, 33818, 7, p. 130.

15 Van der Kroon, Van der Vos \& Meijer 2016, p. 28; P. Disseldorp, De h-grond in de lagere rechtspraak: een verzameling van vreemde eenden, ArbeidsRecht 2016/50, par. 3.4; R.A.A. Duk, Redelijke gronden: een Procrustesbed, TRA 2016/80, p. 9-10; Conclusie plaatsvervangend P-G Langemeijer, par. 2.6-2.8. 
biedt met andere woorden ruimte om de bijzondere arbeidsverhouding van de expat in een internationaal concern te integreren in het Nederlandse ontslagrecht. Deze benadering vind ik goed te begrijpen. Het Gerechtshof Den Haag beschouwde de arbeidsverhouding van de expat 'met het concern' niet zonder reden als totaalpakket: partijen zijn uitdrukkelijk overeengekomen dat de arbeidsovereenkomsten tussen werknemers en de Shell-vennootschappen wordt beheerst door de concernbrede LTIA-regeling, waarin het einde van de uitzending nadrukkelijk is vastgesteld, evenals de wijze waarop daarmee moet worden omgegaan. De hoogopgeleide werknemer wist waar hij voor tekende en koos uitdrukkelijk voor het expatbestaan, in ruil waarvoor hij een riante financiële vergoeding ontving. ${ }^{16}$

De Hoge Raad bevestigt tevens het oordeel van het hof dat de h-grond onder omstandigheden vervuld kan zijn op de enkele grond dat herplaatsing in het concern niet in de rede ligt. Dit is geen vrijbrief voor werkgevers om ontbinding op de h-grond te verzoeken met als enige reden dat herplaatsing niet mogelijk is of niet in de rede ligt. Het oordeel van het hof dat de toets van de redelijke grond en die van herplaatsing samenvallen is beknopt, maar niettemin duidelijk gestoeld op de mobiele en tijdelijke inzetbaarheid van de Shell-expat. De beschikking van het hof gaat uitvoerig in op de arbeidsvoorwaarden van Shell-expats zoals voortvloeien uit de LTIA-regeling, het MOR-systeem en de LOR 2012. Zoals zowel de plaatsvervangend $\mathrm{P}-\mathrm{G}$ als de Hoge Raad benadrukt, overweegt het hof slechts dat in die omstandigheden de twee toetsen samenvallen. Ook dit oordeel is in de bijzondere omstandigheden binnen het Shell-concern begrijpelijk.

\subsection{Verhouding tussen de h- en a-grond in internationale concerns}

Het oordeel van de Hoge Raad dat geen sprake was van een verhulde a-grond verdient om een aantal redenen een nadere analyse. Ten eerste biedt de Hoge Raad, tezamen met de plaatsvervangend P-G, nieuwe inzichten in het belang van het concernlidmaatschap van de werkgever bij de beoordeling of sprake is van een bedrijfseconomische noodzaak voor ontslag. De Shell-beschikking sluit niet uit dat het ontslag van een expat onder het domein van de a-grond valt. In dit verband toont de beschikking interessante parallellen met de lagere rechtspraak over het bedrijfseconomische ontslag van 'bankzitters'. Bijgevolg sta ik tevens kort stil

16 In gelijke zin D.A.D. Mees, annotatie bij Hof Den Haag 19 september 2017, ECLI:NL:GHDHA: 2017:2654, JIN 2018/90, par. 2. Tot een vergelijkbaar oordeel kwam Hof Den Haag 22 november 2016, ECLI:NL:GHDHA:2016:3372, JIN 2017/46, m.nt. Tersteeg. Ook deze beschikking draaide om de LTIA-regeling van het Shell-concern en een werknemer met een arbeidsovereenkomst met SIEP. Nederland was ditmaal de host country. Conform de LTIA-regeling zou de werknemer na het verstrijken van de uitzendtermijn terugkeren naar base country Rusland. Werknemer accepteerde de in Rusland aangeboden functie echter niet en weigerde in te stemmen met de beëindiging van de arbeidsovereenkomst met SIEP. Het hof wees het ontbindingsverzoek op de h-grond toe. Het hof achtte relevant dat in feite sprake was van een driepartijenovereenkomst (tussen de werknemer en de Nederlandse en Russische concernonderdelen), dat de LTIA-regeling ter zake transparant was, dat de tijdelijke aard van de uitzending naar Nederland uitdrukkelijk was overeengekomen, en dat er een uitgebreid herplaatsingstraject en een redelijke afvloeiingsregeling was (r.o. 3.9). 
bij wat het onderbrengen van het ontslag van een expat onder de a-grond zou betekenen voor internationale concerns zoals Shell.

\subsubsection{De relevantie van de bedrijfseconomische omstandigheden in het concern}

In cassatie stond vast dat bij SIEP geen arbeidsplaatsen waren vervallen. De gedachte lijkt te zijn dat de arbeidsplaats van werknemer bij SIEP niet reeds kon zijn vervallen, omdat werknemer nooit arbeid had verricht voor SIEP. Bij de beoordeling van het verhullingsvraagstuk kijkt de Hoge Raad daarentegen verder dan werkgever SIEP. Hij beoordeelt het verhullingsvraagstuk aan de hand van de bedrijfseconomische omstandigheden in het concern. De Hoge Raad wijst op de verschillende sollicitatiepogingen en aanwezige (passende) functies binnen het concern (r.o. 3.3.3). Binnen het concern was werk beschikbaar, zodat de arbeidsplaats van werknemer bij SIEP ook niet hoefde te vervallen. Hierdoor kon van een verhulde a-grond geen sprake zijn.

De vraag is of de betekenis die de Hoge Raad toekent aan het concernverband strookt met de visie van de wetgever. Op het eerste gezicht is dat niet het geval. De wetgever bepaalt in artikel 3 Ontslagregeling dat indien arbeidsplaatsen vervallen bij een werkgever die onderdeel uitmaakt van een concern, de noodzaak voor het vervallen van arbeidsplaatsen wordt beoordeeld aan de hand van de omstandigheden binnen de onderneming van de werkgever en dus niet binnen het concern als geheel. De wetgever erkent dat het voor een verlieslijdende dochter noodzakelijk kan zijn om arbeidsplaatsen te laten vervallen, ondanks dat het concern als geheel winst maakt. ${ }^{17}$ In de toelichting op de Ontslagregeling maakt de wetgever daarentegen duidelijk dat de juridische zelfstandigheid van rechtspersonen wél kan worden gerelativeerd indien het concern in een slechte financiële positie verkeert. In dat geval kan van een (op zichzelf financieel gezonde) dochter offers worden gevraagd die kunnen leiden tot het verval van arbeidsplaatsen bij die dochter. ${ }^{18}$ De wetgever beoogt zo het reorganiseren in concernverband te faciliteren. De benadering van de Hoge Raad sluit hierop aan. Hij toetst immers of de bedrijfseconomische omstandigheden in het concern zouden kunnen noodzaken tot het laten vervallen van arbeidsplaatsen bij SIEP. Dat SIEP deze omstandigheden niet aanvoert om een ontslag op de a-grond te realiseren, maar de Hoge Raad deze omstandigheden beziet bij de toets of oneigenlijk gebruik wordt gemaakt van de h-grond, doet hieraan niet af. Als de werkgever in feite slechte bedrijfseconomische omstandigheden in het concern ten grondslag legt aan een ontslag, moet de rechter die omstandigheden kunnen toetsen.

De Hoge Raad biedt zoals gezegd geen inzicht in de grens tussen verwantschap tussen gronden en verhulling van een grond. De plaatsvervangend P-G doet dat wel. Anders dan de Hoge Raad overweegt de plaatsvervangend P-G dat, hoewel er

17 Toelichting Ontslagregeling, p. 11-12; zie ook Uitvoeringsregels UWV 2018, p. 18-19, en bijv. Ktr. Haarlem 9 juni 2016, ECLI:NL:RBNHO:2016:4789. Deze ratio gaat ook op voor een werkgever die meerdere ondernemingen drijft, zo blijkt uit HR 13 juli 2018, ECLI:NL:HR:2018:1212, NJ 2019/110, m.nt. Bouwens, JAR 2018/202, m.nt. Van Heusden, TRA 2018/89, m.nt. De Laat, JIN 2018/197, m.nt. Kalisvaart \& Schuurman (ANWB).

18 Toelichting Ontslagregeling, p. 11-12; zie ook Uitvoeringsregels UWV 2018, p. 10-11 en 18-19, en bijv. Hof Den Haag 3 januari 2017, ECLI:NL:GHDHA:2017:96, JAR 2017/71. 
binnen het concern in principe werk beschikbaar was voor werknemer (paragraaf 2.12), er wel degelijk slechte bedrijfseconomische omstandigheden in het concern ten grondslag lagen aan de niet-herplaatsbaarheid van werknemer. Meer specifiek noemt de plaatsvervangend P-G drie redenen waarom werknemer niet herplaatsbaar was. De eerste reden is bedrijfseconomisch van aard, namelijk werkvermindering in het concern wegens aanhoudend lage olieprijzen en de overname door Shell van British Gas, in combinatie met stevige concurrentie met goedkope, lokale werknemers (paragraaf 2.13). De tweede reden is de weigering van werknemer de functie van MAA te aanvaarden. De derde reden is de verschillende onsuccesvolle interne sollicitatiepogingen van werknemer binnen het concern. De tweede en derde reden zijn volgens de plaatsvervangend P-G gelegen in de persoon van de werknemer en wegen tezamen zwaarder dan de eerste, bedrijfseconomische reden. Daarom was het ontslag niet overwegend ingegeven door bedrijfseconomische omstandigheden en stond een beroep op de h-grond open (paragraaf 2.15). ${ }^{19}$ De plaatsvervangend P-G biedt rechters hiermee een concreter toetsingskader voor de h-grond dan het niet mogen 'repareren' van een onvoldragen ontslaggrond. Dit toetsingskader is ook voor internationale expats van belang. De Shell-beschikking brengt niet met zich dat een werkgever een ontslag dat volgt uit een concernbreed afvloeiingsbeleid in alle gevallen kan insteken als een h-grond. De Hoge Raad oordeelde in de Shell-casus weliswaar dat niet gebleken was van tot ontslag nopende bedrijfseconomische redenen, maar dit kan in een andere casus anders zijn. Bovendien behoort de beoordeling van de aan- of afwezigheid van een bepaalde ontslaggrond (en dus van bedrijfseconomische redenen) tot het domein van de feitenrechter. Die beoordeling is in cassatie beperkt toetsbaar. ${ }^{20}$ De rechter moet ook na de Shell-beschikking onderzoeken of het ontslag van een expat behoort tot het domein van de a-grond. Daartoe kan de rechter het door de plaatsvervangend $\mathrm{P}-\mathrm{G}$ aangereikte toetsingskader hanteren: de redenen die de werkgever aanvoert voor het ontslag (hier: de niet-herplaatsbaarheid van een expat) mogen niet overwegend zijn gelegen in omstandigheden die behoren tot het domein van de andere ontslaggronden (hier: de tot de a-grond behorende bedrijfseconomische omstandigheden in het concern). ${ }^{21}$

19 De koppeling van de onsuccesvolle sollicitaties aan de persoon van de werknemer acht ik voor nuancering vatbaar. De feiten geven geen inzicht in de reden(en) waarom de sollicitaties van werknemer onsuccesvol waren. Het ligt echter voor de hand dat dit te maken had met de vastgestelde stevige concurrentie met goedkope 'locals' ten gevolge van de werkvermindering in het concern (zie in dit kader ook Hof Den Haag 12 februari 2018, ECLI:NL:GHDHA:2019:182). Op grond van de kenbare feiten lijkt dus behalve de eerste ook de derde door de plaatsvervangend P-G genoemde reden verband te houden met de bedrijfseconomische omstandigheden in het concern. Zo beschouwd, komt in de redenering van de plaatsvervangend P-G de aangevoerde reden voor het ontslag wel erg dicht in de buurt van het domein van de a-grond.

20 Conclusie plaatsvervangend P-G Langemeijer, par. 2.18.

21 De in het wetsvoorstel Wab opgenomen cumulatiegrond (i-grond) gooit voor de expat geen roet in het eten. De i-grond dient slechts ter cumulatie van de gronden c tot en met h (Kamerstukken 2018/19, 35074, 3, p. 54). Door invoering van de i-grond zal het 'verhullingsvraagstuk' voor de gronden $\mathrm{c}$ tot en met $\mathrm{g}$ daarentegen weinig voeten meer in de aarde hebben. 


\subsubsection{De ene expat is de andere niet: vergelijking met de 'bankzitter'}

De expat in de Shell-beschikking was steeds in dienst bij de concernvennootschap bij en voor wie hij arbeid verrichte. Werknemers werken ook op andere wijze voor het Shell-concern. De LTIA-regeling voorziet in de mogelijkheid dat een expat wordt uitgezonden naar een host country onder instandhouding van zijn arbeidsovereenkomst in de base country (de zogenoemde Loan Assignment). Er komt dan geen arbeidsovereenkomst tot stand met de vennootschap in de host country. ${ }^{22}$ Het betreft detachering: de werknemer is in dienst bij de ene vennootschap, maar werkt onder toezicht en leiding van een andere vennootschap. In de lagere rechtspraak is een aantal keer de vraag opgekomen hoe men om moet gaan met de situatie waarin een detacherende werkgever er wegens bedrijfseconomische omstandigheden, zoals een afname in het aantal inleenopdrachten, niet in slaagt om één of meerdere werknemers te detacheren. Men spreekt over 'bankzitters' ${ }^{23}$ Uit de lagere rechtspraak volgt dat, indien een werkgever er wegens gebrek aan werk structureel niet in slaagt om een bankzitter te detacheren, het voor een doelmatige bedrijfsvoering noodzakelijk kan zijn om de arbeidsplaats van de bankzitter te laten vervallen (een a-grond dus). De gedachte is dat, hoewel het bankzitten in beginsel voor rekening en risico van de detacherende werkgever komt, het bedrijfseconomisch niet verantwoord is om deze situatie permanent te laten voortduren. ${ }^{24}$ De vraag rijst of deze gedachte ook na de Shell-beschikking houdbaar is. Dat is het geval. Sterker nog, hoewel er tussen de bankzitter en de werknemer in de Shell-beschikking belangrijke verschillen bestaan, biedt de Shellbeschikking aanknopingspunten om de benadering ten aanzien van bankzitters analoog toe te passen op expats zoals die in de Shell-beschikking. De rechtspraak over bankzitters versterkt met andere woorden de hiervoor uiteengezette

22 Hof Den Haag 9 oktober 2018, ECLI:NL:GHDHA:2018:2551, AR Updates 2018-1155, r.o. 1.2. De beschikking betrof de vraag of niet toch een arbeidsovereenkomst met de inlenende concernvennootschappen was ontstaan. Het Hof Den Haag beantwoordde die vraag conform de heersende leer negatief. Zie over de identificatie van de werkgever onder meer C.J.H. Jansen, Het ontstaan van een arbeidsovereenkomst: de Hoge Raad op het scherp van de snede. HR 5 april 2002, JAR 2002/100 (ABN Amro/Malhi), ArA 2002/2, en E.M. Hoogeveen, De inlener en het werkgeverschap, ArA 2007/3.

23 Ook de werknemer in de Shell-beschikking kan worden gedefinieerd als een bankzitter. Om het onderscheid te bewaren tussen de werknemer in de Shell-beschikking en het type bankzitter in de lagere rechtspraak, zie ik af van die definiëring.

24 Hof Den Bosch 11 november 2012, ECLI:NL:GHSHE:2012:BY8151, AR Updates 2013-0015; Ktr. Rotterdam 28 september 2016, ECLI:NL:RBROT:2016:7424, JAR 2016/274, m.nt. Van Woerden; Ktr. Nijmegen 8 maart 2012, JAR 2012/102; Ktr. Almelo 24 december 2010, ECLI:NL:RBALM: 2010:BO8970, JAR 2011/26; Ktr. Nijmegen 3 mei 2005, ECLI:NL:RBARN:2005:AT9614, JAR 2005/163; Houweling (red.) e.a. 2018, p. 132. Het onderbrengen van het ontslag van bankzitters bij de a-grond past goed in het systeem van de Ontslagregeling. Zo bepaalt artikel 7 Ontslagregeling dat in geval van uitzending (in de zin van artikel 1 onder i Ontslagregeling) het bankzitten vanwege de allocatiefunctie van de uitzendwerkgever snel voor risico van de uitzendwerknemer komt: het beëindigen van een inleenopdracht vormt een a-grond indien aannemelijk is dat de uitzendwerknemer niet binnen 26 weken bij die laatste inlener dezelfde of vergelijkbare werkzaamheden zal kunnen verrichten en de uitzendwerkgever gedurende een redelijke termijn herplaatsingsinspanningen heeft verricht. 
gedachte dat de niet-herplaatsbaarheid van een expat een a-grond kan zijn. Ik leg dit uit.

Een bankzitter is en blijft gedurende de detachering(en) in dienst bij dezelfde werkgever. Het wegvallen van werk bij inleners kwalificeert als werkvermindering voor de werkgever, aangezien het ter beschikking stellen van werknemers een bedrijfsactiviteit van de werkgever is. ${ }^{25}$ Het uitzicht op inleenopdrachten is daardoor een belangrijke omstandigheid in de beoordeling of bij de werkgever een bedrijfseconomische noodzaak bestaat om de arbeidsplaats van een bankzitter te laten vervallen. Om deze reden behoort het ontslag van een bankzitter wegens een gebrek aan inleenopdrachten tot het domein van de a- en dus niet de hgrond. ${ }^{26}$ Voor de Shell-expat is de situatie een andere. ${ }^{27}$ Hij is steeds in dienst bij de 'inlenende' concernvennootschap bij en voor wie hij arbeid verricht. Er is geen sprake van een werkgever met terbeschikkingstelling van werknemers als bedrijfsactiviteit. Daardoor vormt het gebrek aan werk bij andere vennootschappen in beginsel geen bedrijfseconomische reden voor ontslag. De Hoge Raad maakt in de Shell-beschikking echter duidelijk dat, conform de toelichting op artikel 3 Ontslagregeling, ook in deze situatie de bedrijfseconomische omstandigheden bij andere concernvennootschappen betekenis toekomt bij de vraag of sprake is van een a-grond. In een concern maakt het voor het aantonen van een agrond met andere woorden niet uit op wat voor wijze de arbeid in het concern wordt vormgegeven en waar de arbeidsovereenkomst is gesitueerd: op basis van detachering met een arbeidsovereenkomst met de detacherende werkgever of op basis van een arbeidsovereenkomst met het 'inlenende' concernonderdeel. In beide gevallen is het beschikbare werk bij andere concernvennootschappen een relevante bedrijfseconomische omstandigheid voor de werkgever. De rechtspraak over bankzitters kan daarom analoog worden toegepast op concernexpats: het wegens gebrek aan werk structureel niet kunnen herplaatsen van een expat in het concern kan een bedrijfseconomische reden zijn voor het laten vervallen van diens arbeidsplaats. Indien een werkgever overwegend een dergelijke motivering - waarvan in de Shell-beschikking dus niet was gebleken - ten grondslag legt aan het ontslag van een expat, is de a- en dus niet de h-grond de geijkte ontslagroute.

25 Deze redenering doet denken aan HvJ EG 13 september 2007, C-458/05, ECLI:EU:C:2007:512, SR 2008/27, m.nt. Ter Haseborg (Jouini), waarin het Hof van Justitie (voor de toepassing van de Richtlijn overgang van onderneming) overwoog dat uitgezonden werknemers onderdeel uitmaken van de onderneming van de uitzendwerkgever, omdat de onderneming van de uitzendwerkgever bestaat uit het ter beschikking stellen van werknemers.

26 In gelijke zin recent Ktr. Rotterdam 25 april 2019, ECLI:NL:RBROT:2019:3298, AR Updates 2019-0479. Twijfelachtig vind ik de ontbinding op de h-grond in Ktr. Amsterdam 13 oktober 2016, AR Updates 2016-1301, en Ktr. Overijssel 13 december 2018, ECLI:NL:RBOVE:2018:4906, JAR 2019/29. Ook in deze beschikkingen leek het gewenste ontslag van een bankzitter (voornamelijk) ingegeven door het gebrek aan inleenopdrachten. De laatste beschikking betrof overigens payroll, waarvoor par. 7 Ontslagregeling afwijkende regels bevat. Zie in dit kader ook Foesenek in haar annotatie bij de Shell-beschikking in JAR 2019/54, die lijkt te stellen dat het ontslag van een bankzitter altijd is ingegeven door de persoon van de bankzitter.

27 Anders Tersteeg in zijn annotatie bij de Shell-beschikking in JIN 2019/60, die bankzitters en expats zoals die in de Shell-beschikking stilzwijgend op één lijn stelt. 


\subsubsection{Gevolgen van de a-grond: geen bom onder expatarrangementen}

De a-grond perst een werkgever in een strakker keurslijf dan de h-grond. De werkgever kan aan het ontslag slechts bedrijfseconomische redenen ten grondslag leggen en moet het afspiegelingsbeginsel in acht nemen. De vraag is of dit keurslijf verenigbaar is met gedetailleerde, contractuele expatarrangementen zoals de LTIA-regeling. ${ }^{28}$ Mijns inziens is dit het geval. Het uitgangspunt in de Ontslagregeling is dat de werkgever een zekere mate van reorganisatievrijheid toekomt. Het UWV toetst terughoudend of sprake is van een a-grond. ${ }^{29}$ Blijkens de toelichting op artikel 3 Ontslagregeling komt ook het concern deze reorganisatievrijheid toe. Indien het herplaatsingstraject uit een afvloeiingsregels zoals de LTIAregeling daadwerkelijk maar zonder succes is doorlopen, zal het UWV naar mijn inschatting vrij snel aannemen dat het aannemelijk is dat het voor een doelmatige bedrijfsvoering noodzakelijk is dat de arbeidsplaats van de overtollig verklaarde expat moet vervallen.

Toepassing van het afspiegelingsbeginsel op overtollige expats in internationale concerns ligt wat ingewikkelder, maar levert de werkgever evenmin grote problemen op. Voor de toepassing van het afspiegelingsbeginsel staat niet per se dezelfde eenheid centraal als voor de beoordeling van een bedrijfseconomische noodzaak. ${ }^{30}$ Op grond van artikel 14 Ontslagregeling vindt afspiegeling in principe plaats binnen de onderneming of de bedrijfsvestiging van de werkgever waar de arbeidsplaatsen vervallen en dus niet concernbreed. Hoewel de Ontslagregeling ruimte laat om over meerdere rechtspersonen af te spiegelen indien de redelijkheid dit gebiedt, ${ }^{31}$ volsta ik hier met de opmerking dat het niet direct redelijk is om van een werkgever te verlangen dat hij over alle vestigingen van een internationaal of zelfs wereldwijd opererend concern afspiegelt. ${ }^{32}$ Belangrijker is

Men kan zich die vraag overigens stellen ten aanzien van meerdere bepalingen van titel 7.10 BW.

Toelichting Ontslagregeling, p. 10.

Zie ook Bouwens in zijn annotatie bij de ANWB-beschikking in NJ 2019/110, par. 8.

Toelichting Ontslagregeling, p. 20-21. Dit is volgens de wetgever bijvoorbeeld aan de orde wanneer verschillende rechtspersonen zelf geen zelfstandige bedrijfsvoering hebben of regelmatig personeel uitwisselen.

Rechtspersoonoverstijgende afspiegeling gaat ver. Het kan ertoe leiden dat het UWV de ontslagvergunning weigert omdat een andere werknemer, die in dienst is bij een andere werkgever, eerst voor ontslag in aanmerking komt. Dit staat op gespannen voet met de contractuele benadering van het werkgeverschap en de juridische zelfstandigheid van rechtspersonen (zie ook hierna, in het kader van herplaatsing, par. 6.2.2); zie ook R.A.C.G. Martens, Anciënniteit en concern-verband, ArbeidsRecht 1997/48. Uit de (schaars) gepubliceerde rechtspraak leid ik voorzichtig af dat rechtspersoonoverstijgende afspiegeling niet snel wordt aangenomen; RDA Dordrecht 10 mei 1993, JAR 1993/209; UWV WERKbedrijf Zuid West Nederland juni 2009, nr. 2009000043 (besproken in L.R. Kenens \& R.A. Koster-Mulder, To whom it may concern, ArbeidsRecht 2010/4); Ktr. Bergen op Zoom 22 juli 2009, ECLI:NL:RBBRE:2009:BJ3353, RAR 2009/140; Ktr. Amersfoort 16 september 2010, ECLI:NL:RBUTR:2010:BN8123, RAR 2010/17; Ktr. Arnhem 3 maart 2014, ECLI:NL:RBGEL:2014:1410, AR Updates 2014-0212; Ktr. Alkmaar 25 oktober 2017, ECLI:NL:RBNHO:2017:9361, JAR 2017/301; zie ook M.A. de Blécourt, M. Diepenbach \& R. Hampsink, Maatwerk bij het bepalen van de ontslagvolgorde, in: L.C.J. Sprengers \& G.W. van der Voet, Arbeidsrechtelijke reflecties 2014 (reeks VvA 42), Deventer: Kluwer 2014, p. 175-176; H. Dammingh \& S. Gerdes, De vaststelling van de bedrijfsvestiging: een riskante zaak, ArbeidsRecht 2014/14. 
namelijk dat het afspiegelingsbeginsel uitgaat van de arbeidsplaatsen die vervallen, alsmede de daarmee uitwisselbare functies. ${ }^{33}$ Hiervoor bleek dat bedrijfseconomische omstandigheden concernbreed kunnen worden getoetst. De arbeidsplaatsen die vervolgens komen te vervallen zijn en blijven echter arbeidsplaatsen binnen de onderneming van de werkgever. ${ }^{34}$ Dit betekent volgens mij voor een expat als die in de Shell-beschikking dat de arbeidsplaats die vervalt niet de expatfunctie van de werknemer 'binnen het concern' is, maar het dienstverband van de expat met zijn tot ontslag verzoekende werkgever. Voor een expat als die in de Shell-beschikking houdt dit dienstverband niet meer in dan een betrekking van waaruit de expat nog enige tijd kan zoeken naar een nieuwe functie. De expat kan om deze reden niet stellen dat op grond van het afspiegelingsbeginsel niet hij maar een andere, wel in het concern geplaatste werknemer in aanmerking komt voor ontslag. ${ }^{35}$ Het betreft namelijk geen met elkaar uitwisselbare functies. Dit lijkt mij een redelijke uitkomst. Zij sluit aan bij het expatarrangement waarin duidelijk is afgesproken onder welke omstandigheden afscheid wordt genomen van niet-herplaatsbare expats. Daarbij past niet dat de expat alsnog af kan dwingen dat niet hij maar een andere werknemer, die in dienst is bij een ánder concernonderdeel, moet worden ontslagen. ${ }^{36}$ De expat heeft bij afspiegeling de functie bovendien niet voor het uitkiezen. Indien de werkgever over een internationaal concern zou moeten afspiegelen, is het goed mogelijk dat de expat in aanmerking komt voor een functie of standplaats in het buitenland die hem niet bevalt. ${ }^{37}$ Ook dit pleit voor een restrictieve uitleg van het begrip arbeidsplaats.

\section{Het juridische karakter en de reikwijdte van het herplaatsingsvereiste in concernverband}

\subsection{Geen breuk met het oude recht}

Ten aanzien van het herplaatsingsvereiste overweegt de Hoge Raad dat de wetgever geen wijziging heeft beoogd ten opzichte van het oude recht en dat de herplaatsingstoets daarom ruimte laat voor redelijkheidsargumenten. Op het eerste gezicht verbaast deze overweging. Voor de Shell-beschikking wezen de neuzen in

33 Dat wil zeggen: functies die met elkaar vergelijkbaar zijn voor zover het betreft de inhoud van de functie en de voor de functie vereiste kennis, vaardigheden en competenties en die gelijkwaardig zijn als het gaat om het niveau van de functie en de bij de functie behorende beloning (artikel 13 lid 1 Ontslagregeling). Deze beoordelingscriteria zijn cumulatief; HR 15 februari 2019, ECLI:NL:HR:2019:229, JAR 2019/74, m.nt. Van Herk.

34 Artikel 1 onder c jo. 3 Ontslagregeling; Toelichting Ontslagregeling, p. 11-12; Uitvoeringsregels UWV 2018, p. 18-19.

35 Hetzelfde geldt voor artikel 7:671a lid 5 BW, dat bepaalt dat de werkgever eerst afscheid moet nemen van flexkrachten die werkzaam zijn op 'de arbeidsplaatsen die vervallen'.

36 De expat loopt tevens aan tegen beperkingen van internationaal privaatrechtelijke aard. Het UWV betrekt bij de afspiegeling slechts werknemers met een arbeidsovereenkomst waarop op grond van artikel 8 Rome I-Verordening (Verordening 539/2008) objectief gezien het Nederlandse recht van toepassing is (Uitvoeringsregels UWV 2018, p. 40). Werknemers in dienst van buitenlandse concernonderdelen vallen reeds hierdoor (normaliter) buiten de boot.

37 Zie over die problematiek nader A.W. Haverkort \& L.E.J. Kiebert, Bedrijfseconomisch ontslag: toe aan een nieuwe fase, TAP 2017/262, par. 3. 
de literatuur redelijk consequent de andere kant op: het herplaatsingsvereiste was onder de Wwz op een andere leest geschoeid dan onder het oude recht. ${ }^{38}$ Toch is de overweging van de Hoge Raad goed te begrijpen. Onder het oude recht toetste het UWV op grond van artikel 3:1 Ontslagbesluit (oud) of een voorgenomen ontslag redelijk was. Daarbij nam het UWV onder andere in aanmerking of de werkgever voldoende herplaatsingsinspanningen had geleverd. De herplaatsingstoets vloeide voort uit een aan het goed werkgeverschap gekoppelde redelijkheidsnorm. Alles wat binnen een redelijk bereik van de werkgever lag, mocht worden gevergd. ${ }^{39}$ Koos de werkgever voor de ontslagroute bij de kantonrechter (artikel 7:681 of 7:685 (oud) BW), dan werden de te vergen inspanningen getoetst aan de norm van het goed werkgeverschap. ${ }^{40}$ Met de invoering van de Wwz formuleerde de wetgever één herplaatsingsvereiste voor zowel de kantonrechter als het UWV. Tijdens het wetgevingstraject stelde de wetgever meermaals dat hij geen wijziging beoogde ten opzichte van de herplaatsingseisen die het UWV voorheen stelde. ${ }^{41}$ Deze stelling is in de literatuur in twijfel getrokken. De kritiek komt er enerzijds op neer dat de tekst van artikel 7:669 BW in de weg staat aan een redelijkheidstoets (indien herplaatsing mogelijk is, moet worden herplaatst; 'in de rede' is niet hetzelfde als 'redelijkheid'), en behelst anderzijds dat de wetgever in de toelichting op de Ontslagregeling een striktere invulling geeft aan het herplaatsingsvereiste dan het UWV voorheen deed. Zo haalde de werknemer in de Shell-beschikking een opmerking van de regering aan dat een met ontslag bedreigde werknemer met voorrang moet worden geplaatst boven een externe kandidaat bij een ander concernonderdeel, ${ }^{42}$ terwijl dit onder het oude recht geenszins het uitgangspunt was (zie hierna paragraaf 6.2). Aan de andere kant werd betoogd dat de wetgever altijd duidelijk is geweest: er is geen breuk met het oude recht beoogd. Dat hij in de toelichting op de Ontslagregeling vervolgens blijk geeft van een verkeerde voorstelling van zaken, doet daar niet aan af. ${ }^{43}$ De op resultaat gerichte terminologie in artikel 7:669 BW is bovendien te plaatsen in het licht van het vervallen van de algemene redelijkheidstoets van artikel 3:1 Ontslagbesluit. ${ }^{44}$ Het uitgangspunt ten aanzien van herplaatsing zou ondanks de opmerkingen van de wetgever dus toch ongewijzigd gebleven zijn: het gaat om wat in een concreet geval redelijk is. Deze mening is ook de Hoge Raad toegedaan. De redelijkheidstoets is volgens de Hoge Raad nooit weggeweest en moet worden gelezen in het begrippenpaar of herplaatsing niet mogelijk is of niet in de rede ligt. Hiermee komt de Hoge Raad impliciet ook tegemoet aan het tweede kritiekpunt uit de literatuur: de stellige overwegingen van de wetgever in de toelichting

Zie de in noot 2 genoemde literatuur, alsmede Conclusie plaatsvervangend P-G Langemeijer, par. 2.25-2.27 en 2.33, en Conclusie A-G De Bock voor Bossers \& Cnossen, ECLI:NL:PHR:2017:1256, par. 3.34.

39 Beleidsregels Ontslagtaak UWV 2015, hfdst. 20.

40 Zie, ten aanzien van het concern, de hierna in noot 53 genoemde jurisprudentie.

41 Kamerstukken II 2013/14, 33818, 3, p. 43 en 98; Kamerstukken II 2013/14, 33818, 7, p. 85; Handelingen II 2013/14, 33818, 54, item 9, p. 20.

42 Toelichting Ontslagregeling, p. 15.

43 Houweling (red.) e.a. 2018, p. 57; Olivier \& Wiewel 2017, p. 8.

44 Beltzer \& Schmeetz 2017, p. 65. 
op de Ontslagregeling kunnen worden genuanceerd door toepassing van de redelijkheidstoets. ${ }^{45}$ De Hoge Raad neemt dezelfde route als in de Mediant-beschikking: ${ }^{46}$ aan ondoordachte opmerkingen van de wetgever tijdens het wetgevingstraject komt weinig waarde toe.

Interessant is nog de overweging van de Hoge Raad dat de term 'in de rede' ruimte laat voor redelijkheidsargumenten en dat de werkgever daarmee 'een zekere beoordelingsruimte' wordt gelaten (r.o. 3.4.2). De overweging is een reactie op de cassatieklacht dat de term 'in de rede' slechts ziet op de gevallen waarin evident is dat van herplaatsing geen sprake kan zijn. ${ }^{47}$ De vraag rijst waar de door de Hoge Raad genoemde beoordelingsruimte op ziet. De uitdrukking dat de werkgever een zekere beoordelingsruimte toekomt, bezigt de Hoge Raad in recente ontslagbeschikkingen vaker en heeft verschillende betekenissen. ${ }^{48}$ Met het gebruik van het verbindingswoord 'daarmee' impliceert de Hoge Raad dat de beoordelingsruimte ten aanzien van herplaatsing is gelegen in het bestaan van de redelijkheidsnorm. Volgens mij moet men de overweging van de Hoge Raad echter lezen in lijn met de conclusie van de plaatsvervangend P-G, die stelt dat de werkgever bij de beoordeling of gebruik van een herplaatsingsmogelijkheid in een concreet geval in de rede ligt enige beoordelingsruimte toekomt (paragraaf 2.35). De beoordelingsruimte ziet op de benodigde onderbouwing van de werkgever om het UWV of de kantonrechter ervan te overtuigen dat herplaatsing niet in de rede ligt. Eenzelfde beoordelingsruimte bestaat ten aanzien van de vraag of de werkgever voldoende naar herplaatsingsmogelijkheden heeft gezocht om te kunnen concluderen dat herplaatsing niet mogelijk is. Voor beide facetten van de herplaatsingstoets strookt het gunnen van een zekere beoordelingsruimte op het punt van bewijs namelijk met de situatie onder het oude recht. Het UWV beoordeelde (zoals het nog steeds doet) een aanvraag voor een ontslagvergunning op basis van aannemelijkheid. Onder de oude beleidsregels moest de werkgever aannemelijk maken dat er geen herplaatsingsmogelijkheden waren dan wel dat het redelijkerwijs niet van hem gevraagd kon worden de werknemer te herplaatsen. ${ }^{49}$ De aannemelijkheidsmaatstaf dicteert de wijze waarop het UWV en de rechter de vaststaande feiten waarderen. Aannemelijkheid betekent dat het niet onomstotelijk of met een bepaalde mate van zekerheid hoeft vast te staan dat herplaatsing niet

45 Idem het Gerechtshof Den Haag in de bestreden beschikking, r.o. 9.

46 HR 23 december 2016, ECLI:NL:HR:2016:2998, NJ 2017/203, m.nt. Verhulp, TRA 2017/19, m.nt. Buijs, AA 2017/0434, m.nt. Bouwens, JAR 2017/19, m.nt. Van Zanten-Baris, AR Updates 2016-1482, m.nt. Kruit (Mediant), r.o. 3.17.2. Het betrof de (niet-)toepasselijkheid van het bewijsrecht op voorwaardelijke ontbindingsverzoeken. Voor een analoge toepassing van de Mediant-beschikking pleitten reeds Olivier \& Wiewel 2017, p. 6 en 8.

47 In gelijke zin De Graaf 2016, p. 17; Beltzer \& Schmeetz 2017, p. 65; Conclusie A-G De Bock voor Bossers \& Cnossen, ECLI:NL:PHR:2017:1256, par. 3.34.

48 Zie R.A.A. Duk, 'Een zekere mate van beoordelingsruimte', en het bewijsrecht bij de beoordeling van een 'redelijke grond' voor ontslag, ArbeidsRecht 2018/42.

49 Beleidsregels Ontslagtaak UWV 2015, hfdst. 7, par. 5 en hfdst. 20, inleiding; in gelijke zin Kamerstukken II 2013/14, 33818, 3, p. 44; Stcrt. 2018, nr. 42718, p. 2; Uitvoeringsregels UWV 2018, p. 6. 
mogelijk is of niet in de rede ligt. ${ }^{50}$ Beslissend is of de werkgever op grond van de vaststaande feiten in redelijkheid heeft kunnen concluderen dat herplaatsing niet mogelijk is of niet in de rede ligt.

\subsection{Herplaatsing in concernverband: a matter of concern}

$\mathrm{Na}$ de overweging dat herplaatsing nog altijd een redelijkheidsventiel kent, komt de beschikking van de Hoge Raad vrij abrupt tot een einde: de overige klachten van het middel kunnen niet tot cassatie leiden. De Hoge Raad gaat niet in op de cassatieonderdelen die zagen op de reikwijdte van het herplaatsingsvereiste in concernverband, zoals de vraag of een met ontslag bedreigde werknemer voorrang heeft boven externe kandidaten in het concern. Ik lees de beschikking van de Hoge Raad zo dat concerngerelateerde herplaatsingsvraagstukken moeten worden opgelost via de redelijkheidsnorm. Dit strookt met de situatie voor de Wwz. De oude beleidsregels van het UWV brachten tot uitdrukking dat binnen een concern mocht worden verwacht dat de werkgever onderzocht of herplaatsing bij een zustervennootschap mogelijk was. ${ }^{51}$ De redelijkheidsnorm gaf het UWV een flexibel beoordelingskader waarmee het kon inspelen op de enorme diversiteit aan concernverbanden. ${ }^{52}$ Hetzelfde gold via de norm van het goedwerkgeverschap voor de kantonrechter. ${ }^{53}$ In beide gevallen kleurden de omstandigheden in het concern, zoals de verwevenheid tussen de concernonderdelen en de mate van zeggenschap van de werkgever over de andere concernonderdelen, de reikwijdte van de inspanningsverplichting tot herplaatsing in het concern.

De Shell-beschikking biedt de praktijk geen concrete handvatten omtrent de in een concreet geval vereiste inspanningen tot concernbrede herplaatsing. Met de overweging dat de te vergen inspanningen worden gekleurd door de omstandigheden van het geval, is nog niet duidelijk hoe die inspanningen moeten worden beoordeeld. Een deel van de Wwz-rechtspraak was wel bereid om de omstandigheden van het geval mee te wegen, maar welke omstandigheden dat zijn en hoe de rechter die omstandigheden waardeert, loopt uiteen. Daarom inventariseer ik hierna in het licht van de Shell-beschikking enkele gezichtspunten omtrent de reikwijdte van de inspanningsverplichting tot herplaatsing in het concern. Ik put inspiratie uit de rechtspraak en de beleidsregels van het UWV van voor en na de

50 Vgl. F.G. Laagland, annotatie bij Hoge Raad 16 februari 2018, ECLI:NL:HR:2018:182 en ECLI:NL:HR:2018:220, AR Updates AR 2018-0214 en 2018-0216, par. 3.1-3.2.

51 Beleidsregels Ontslagtaak UWV 2015, hfdst. 20, par. 2.

52 De Graaf 2016, p. 16; Verburg 2017, p. 331; zie ook RDA Dordrecht 10 mei 1993, JAR 1993/209; CWI Zuid West Nederland (locatie Breda) 28 maart 2007, nr. 2007000126 (besproken in Kenens \& Koster-Mulder 2010).

53 Bijv. HR 21 mei 2010, ECLI:NL:HR:2010:BL6075, NJ 2010/495, m.nt. Heerma van Voss (Hoedjes/VWTI); Hof Leeuwarden 14 oktober 2008, ECLI:NL:GHLEE:2008:BG3269, JAR 2008/317; Hof Den Bosch 10 maart 2009, ECLI:NL:GHSHE:2009:BH5994, AR Updates 2009-0177; Hof Den Bosch 8 januari 2013, ECLI:NL:GHSHE:2013:BY8167, AR Updates 2013-0014; Hof ArnhemLeeuwarden 7 mei 2013, ECLI:NL:GHARL:2013:CA2648, AR Updates 2013-0476; Hof Den Bosch 11 november 2014, ECLI:NL:GHSHE:2014:4662, JIN 2015/4, m.nt. Van den Honert. Afwijkend oordeelde Hof Leeuwarden 3 april 2012, ECLI:NL:GHLEE:2012:BW0809, AR Updates 2012-0320. 
Wwz. ${ }^{54}$ De gezichtspunten zien op drie concernspecifieke knelpunten van herplaatsing: de reikwijdte van de onderzoeksplicht naar passende functies in het concern, de vraag of een werknemer elders in het concern voorrang heeft boven externe kandidaten, en in hoeverre de concernbrede herplaatsingsplicht betrekking heeft op plaatsmakersfuncties.

\subsubsection{De reikwijdte van de onderzoeksplicht}

Duidelijk is dat indien een werkgever onderdeel uitmaakt van een concern, hij de herplaatsingsmogelijkheden in het concern moet onderzoeken. ${ }^{55}$ De werkgever dient aannemelijk te maken dat er binnen een redelijke termijn binnen het concern geen passende functie voorhanden is of zal komen. Daarvoor moet hij de vacatures bij de andere concernonderdelen inventariseren. ${ }^{56}$ De vraag of de werkgever voldoende inspanningen heeft verricht om de vacatures bij de andere concernonderdelen te inventariseren, hangt (mede) af van de omstandigheden binnen het concern. Uit de rechtspraak en de beleidsregels van het UWV blijkt dat men kan denken aan:

- een nauwe verwevenheid tussen de concernonderdelen (die zich bijvoorbeeld uit in de concernbrede inzet van personeel, de aanwezigheid van een interne vacaturebank of, zoals in de Shell-beschikking, een concernbreed herplaatsingsbeleid); ${ }^{57}$

54 De beleidsregels van het UWV binden de rechter niet, maar hij kan daarop wel acht slaan. Dit geldt des te meer voor de vervallen beleidsregels, nu uit de totstandkomingsgeschiedenis van de Wwz blijkt dat het herplaatsingsvereiste aan deze oude beleidsregels is ontleend (vgl. HR 16 februari 2018, ECLI:NL:HR:2018:182, NJ 2018/394, m.nt. Verhulp, TRA 2018/49, m.nt. Frikkee, Ondernemingsrecht 2018/50, m.nt. Van Slooten, JAR 2018/72, m.nt. Koole, AR Updates 2018-0214, m.nt. Laagland (Decor), r.o. 3.4.7, waarnaar de Hoge Raad in r.o. 3.4.2 van de Shellbeschikking verwijst).

55 Afwijkend oordeelden Ktr. Alkmaar 31 mei 2017, ECLI:NL:RBNHO:2017:4396 en Ktr. Roermond 14 juni 2017, ECLI:NL:RBLIM:2017:5521, JAR 2017/175, waar werd overwogen dat de inspanningsverplichting slechts bestaat indien de werkgever zeggenschap heeft over de andere concernvennootschappen.

56 Zie ook Uitvoeringsregels UWV 2018, p. 76. Weigert de werknemer een passende functie, dan ligt herplaatsing in beginsel niet in de rede (Conclusie plaatsvervangend P-G Langemeijer, par. 2.34). Uitzonderingen op deze regel zijn mogelijk. De aangeboden functie kan weliswaar passend zijn (in de zin van artikel 9 lid 3 Ontslagregeling), maar voor de werknemer bijvoorbeeld niet bereisbaar zijn. In dat geval ligt herplaatsing in die passende functie niet in de rede en mag van de werkgever worden verwacht dat hij een andere passende functie onderzoekt. Blijkens de Shellbeschikking spelen redelijkheidsargumenten immers een rol. Het lijkt mij dat dit twee kanten op werkt. Zo ook Hof Arnhem-Leeuwarden 13 januari 2017, ECLI:NL:GHARL:2017:252, en vgl. HR 3 september 2010, ECLI:NL:HR:2010:BM7049, NJB 2010/1659, JAR 2010/250, r.o. 3.4.

57 Hof Arnhem-Leeuwarden 7 mei 2013, ECLI:NL:GHARL:2013:CA2648, AR Updates 2013-0476; Hof Den Bosch 11 november 2014, ECLI:NL:GHSHE:2014:4662, JIN 2015/4, m.nt. Van den Honert; Ktr. Rotterdam 31 maart 1992, ECLI:NL:RBROT:1992:AG0274, JAR 1992/48; Ktr. Amsterdam 29 november 2018, ECLI:NL:RBAMS:2018:8549, AR Updates 2018-1419. 
- de zeggenschap van de werkgever over andere concernvennootschappen (de werkgever is de moedervennootschap of deelt één of meerdere bestuurders met andere concernvennootschappen); ${ }^{58}$

- de economische omstandigheden bij de andere concernonderdelen (hoe slechter de omstandigheden, hoe minder aannemelijk het is dat er passende functies voorhanden zijn); 59

- of de leidinggevende van de werknemer bij de werkgever tevens leidinggevende is bij andere concernvennootschappen; 60

- de omvang van het concern (hoe groter het concern, hoe aannemelijker het is dat er passende functies voorhanden zijn); ${ }^{61}$ en

- de aanwezigheid van een sociaal plan waarin een werkgever toezegt een concrete inspanning tot concernbrede herplaatsing te leveren. ${ }^{62}$

De werkgever kan de reikwijdte van de onderzoeksplicht voorts beperken door met de werknemer af te bakenen tot waar in het concern herplaatsing voor de werknemer acceptabel is. ${ }^{63}$ Dit kan met name uitkomst bieden voor de werkgever in een groot internationaal concern die geen overzicht heeft van de vacatures bij de talloze andere concernonderdelen, bijvoorbeeld omdat een interne vacaturebank ontbreekt. ${ }^{64}$

\subsubsection{De voorrangskwestie}

Als duidelijk is dat bij een van de concernonderdelen een passende functie voorhanden is, mag van de werkgever worden verwacht dat hij alles doet wat redelijkerwijs in zijn macht ligt om ervoor te zorgen dat het betreffende concernonderdeel de werknemer in dienst neemt. Kruit en Sap betogen dat indien de werkgever er niet in slaagt een zustervennootschap te bewegen tot indienstneming, het

58 Hof Den Bosch 8 januari 2013, ECLI:NL:GHSHE:2013:BY8167, AR Updates 2013-0014; Ktr. Amsterdam 4 februari 1987, ECLI:NL:RBAMS:1987:AL1873, Prg. 1987/2694; RDA Dordrecht 10 mei 1993, JAR 1993/209; Ktr. Amsterdam 27 maart 2007, ECLI:NL:RBAMS:2007:BA4000, JAR 2007/97.

59 Ktr. Amsterdam 4 juni 1987, ECLI:NL:KTGAMS:1987:AB8806, NJ 1988/577; Rb. Den Haag (pres.) 26 januari 1996, JAR 1996/58, TVVS 1996/114, m.nt. Lennarts \& De Valk; Ktr. Utrecht 7 augustus 2009, ECLI:NL:RBUTR:2009:BJ4830, JIN 2009/601.

60 Hof Den Bosch 10 maart 2009, ECLI:NL:GHSHE:2009:BH5994, AR Updates 2009-0177.

61 Beleidsregels Ontslagtaak UWV 2015, hfdst. 20, par. 2; Hof Den Haag 19 september 2017, ECLI:NL:GHDHA:2017:2654, JIN 2018/90, m.nt. Mees; Ktr. Maastricht 25 juli 2002, ECLI:NL:RBMAA:2002:AG7970, JAR 2002/285; Ktr. Utrecht 7 augustus 2009, ECLI:NL:RBUTR: 2009:BJ4830, JIN 2009/601; Ktr. Rotterdam 16 februari 2016, ECLI:NL:RBROT:2016:1185, AR Updates 2016-0145; Ktr. Leeuwarden 19 oktober 2016, ECLI:NL:RBNNE:2016:4611, AR Updates 2016-1245; Ktr. Utrecht 18 januari 2017, ECLI:NL:RBMNE:2017:600, AR Updates 2017-0151; Ktr. Amsterdam 20 januari 2017, ECLI:NL:RBAMS:2017:842, AR Updates 2017-0174; Ktr. Leeuwarden 22 maart 2017, ECLI:NL:RBNNE:2017:973, AR Updates 2017-0333; Ktr. Amsterdam 17 juli 2018, ECLI:NL:RBAMS:2018:5116, JIN 2018/200, m.nt. Beudeker \& Smeets.

62 Beleidsregels Ontslagtaak UWV 2015, hfdst. 20, par. 4c; Ktr. Utrecht 21 december 2016, ECLI:NL:RBMNE:2016:6916, JAR 2017/44; Ktr. Maastricht 29 mei 2017, ECLI:NL:RBLIM: 2017:4850, AR Updates 2017-0690.

63 Uitvoeringsregels UWV 2018, p. 75-76; in gelijke zin Hof Den Bosch 6 december 2018, ECLI:NL:GHSHE:2018:5118, JAR 2019/13, m.nt. Otto.

Vgl. Olivier \& Wiewel 2017, p. 7-8. 
UWV geen toestemming voor opzegging kan verlenen en de kantonrechter de arbeidsovereenkomst niet kan ontbinden. ${ }^{65}$ Deze resultaatgerichte benadering verhoudt zich niet met het oude recht, dat uitgaat van een inspanningsverplichting. Zij staat bovendien op gespannen voet met de ondernemersvrijheid van artikel 16 van het Handvest van de grondrechten van de Europese Unie (hierna: Handvest). ${ }^{66}$ In een concernverband vindt artikel 16 Handvest al snel toepassing. De aanwezigheid van een buitenlandse moedervennootschap volstaat: dit activeert het vrij verkeer van vestiging ${ }^{67}$ en daarmee artikel 16 Handvest. ${ }^{68}$ Artikel 16 Handvest verschaft de werkgever een zekere ondergrens aan handelingsvrijheid bij de vormgeving van de arbeidsverhouding. De werkgever moet zijn belangen op doeltreffende wijze kunnen doen gelden. ${ }^{69}$ De handelingsvrijheid omvat onder andere het recht om eenzijdig tot ontslag over te kunnen gaan. Cruciaal is dat de werkgever hiertoe niet iedere mogelijkheid mag worden ontnomen. ${ }^{70}$ Die handelingsvrijheid wordt met voeten getreden indien de toelaatbaarheid van een ontslag afhangt van de bereidheid van een andere rechtspersoon, zonder dat de werkgever hier invloed op heeft.

De werkgever heeft normaliter ook niet de plicht om indienstneming af te dwingen via de centrale leiding. Het bestaan van een concern (en dus van een concernbrede herplaatsingsplicht) vereist de aanwezigheid van centrale leiding. ${ }^{71}$ Centrale leiding impliceert echter geenszins dat de moedervennootschap beslist welke concernvennootschap wie in dienst neemt. De hoofdregel is en blijft dat het bestuur van de dochter de eigen vennootschap bestuurt en daarbij een zekere autonomie toekomt. ${ }^{72}$ In normale concernverhoudingen zal juist bij de personele bezetting een moedervennootschap ervoor waken op de stoel van het bestuur van een dochter te gaan zitten. Hoe groter de inmenging van de concernleiding op dochterniveau, des te groter het risico op aansprakelijkheid jegens de crediteuren van de dochter, waaronder werknemers. ${ }^{73}$ Met de vennootschapsrechtelijke benadering strookt dus niet dat van een werkgever verwacht wordt dat hij zijn moedervennootschap ertoe zet om in te grijpen in het autonome personeelsbeleid van een andere dochter. Dit geldt des te meer in een internationaal concern. Een moe-

Kruit \& Sap 2018, p. 40; idem G.J.J. Heerma van Voss, in: Verslag Preadvies concernwerkgeverschap 21 mei 2015, Deventer: Kluwer 2015, p. 211.

66 Zie over artikel 16 Handvest en herplaatsing ook B.P. ter Haar, Sociaal recht in conflict met de vrijheid van ondernemerschap: is het HvJ EU een nieuwe constitutionele rechter?, TAP 2018/61, p. 29.

67 Artikel 49 Verdrag betreffende de werking van de Europese Unie.

68 Bijv. HvJ EU 21 december 2016, C-201/15, ECLI:EU:C:2016:972, JAR 2017/37, m.nt. Laagland, TRA 2017/34, m.nt. Voogsgeerd (AGET Iraklis).

69 Bijv. HvJ EU 18 juli 2013, C-426/11, ECLI:EU:C:2013:521, NJ 2013/569, m.nt. Mok, JAR 2013/216, m.nt. Beltzer, JIN 2013/127, m.nt. Blom, TRA 2013/107, m.nt. Voogsgeerd (Parkwood).

70 AGET Iraklis, r.o. 88.

71 Asser/Maeijer \& Kroeze 2-I 2015/261.

72 Zo ook Verburg 2017, p. 333. Anders lijkt te veronderstellen Otto, annotatie bij Hof Den Bosch 6 december 2018, ECLI:NL:GHSHE:2018:5118, JAR 2019/13.

73 M. Olaerts, Concerndilemma's: laveren tussen de economische werkelijkheid en de juridische benadering van het concern, in: Verwey (red.) 2017, p. 14; Verburg 2017, p. 333. 
dervennootschap kan een uit het op haar toepasselijke vennootschapsrecht voortvloeiend instructierecht niet uitoefenen op buitenlandse dochtervennootschappen indien het vennootschapsrecht van de dochter dit instructierecht niet erkent. $^{74}$

Als de werkgever het concernonderdeel daadwerkelijk maar zonder succes heeft proberen te bewegen tot indienstneming, dan ligt herplaatsing bij dat concernonderdeel in principe niet in de rede. De werkgever moet wel motiveren waarom dit hem niet is gelukt. ${ }^{75}$ Deze verplichting is te concretiseren door van de werkgever te verlangen dat hij een degelijke onderbouwing van het weigerende concernonderdeel overlegt. ${ }^{76}$ Voor de vraag hoe sterk de onderbouwing moet zijn, kunnen de in paragraaf 6.2.1 genoemde gezichtspunten worden gehanteerd.

Het voorgaande betekent niet dat nooit van de werkgever kan worden verwacht dat hij een ander concernonderdeel dwingt een werknemer te herplaatsen. ${ }^{77}$ Denk bijvoorbeeld aan de situatie waarin de werkgever formele of feitelijke zeggenschap heeft over het aannamebeleid van het betreffende concernonderdeel. Indien deze zeggenschap bestaat, is het redelijk dat de werkgever deze uitoefent om zijn met ontslag bedreigde werknemers te herplaatsen. ${ }^{78}$ Eenzelfde redenering gaat op indien de moedervennootschap (niet zijnde de werkgever) in de praktijk beslist welke concernvennootschap wie in dienst neemt. ${ }^{79}$ In deze situatie kan van de werkgever worden verlangd dat hij de moeder beweegt tot het inzetten van haar zeggenschap. ${ }^{80}$ Ik meen dat een moedervennootschap in de regel mee zal werken aan een dergelijk verzoek. Dit is in haar belang. Het financiële nadeel dat de dochter-werkgever ondervindt als zij de werknemer niet kan ontslaan, sijpelt door naar de moedervennootschap als (groot)aandeelhouder. ${ }^{81}$

Asser/Kramer \& Verhagen 10-III 2015/13; M. Olaerts, Eenheid en verscheidenheid in concernverhoudingen, Ondernemingsrecht 2016/75, p. 359-360.

75 Zie Conclusie plaatsvervangend P-G Langemeijer, par. 2.30, en de daar genoemde jurisprudentie.

76 Een dergelijke benadering is het Nederlandse ontslagrecht niet vreemd. Zo dient een payrollwerkgever in bepaalde gevallen aannemelijk te maken dat herplaatsing bij een van de inleners niet mogelijk is. Hij dient hiervoor informatie van de inleners te verkrijgen; Toelichting Ontslagregeling, p. 27.

77 Conclusie plaatsvervangend P-G Langemeijer, par. 2.37.

78 Hof Den Bosch 8 januari 2013, ECLI:NL:GHSHE:2013:BY8167, AR Updates 2013-0014; Ktr. Amsterdam 4 februari 1987, ECLI:NL:RBAMS:1987:AL1873, Prg. 1987/2694; RDA Dordrecht 10 mei 1993, JAR 1993/209; Ktr. Amsterdam 27 maart 2007, ECLI:NL:RBAMS:2007:BA4000, JAR 2007/97.

79 Zie bijv. de casus die leidde tot Ktr. Alkmaar 6 januari 2017, ECLI:NL:RBNHO:2017:868, AR Updates 2017-0404.

80 Deze situatie deed zich in de Shell-beschikking overigens niet voor: de concernonderdelen behielden autonomie in hun aannamebeleid. Zie in gelijke zin Ktr. Bergen op Zoom 16 maart 2018, ECLI:NL:RBZWB:2018:1800, AR Updates 2018-041.

81 Vgl. Conclusie A-G Sharpston bij HvJ EU 7 augustus 2018, gevoegde zaken C-61/17, C-62/17 en C-72/17 (ECLI:EU:C:2018:482). Artikel 2 lid 4 van de Richtlijn collectief ontslag legt de werkgever de plicht op om, als een collectief ontslag wordt opgelegd door een moedervennootschap, de werknemersvertegenwoordiging inzicht te geven in de besluitvorming van de moeder. Volgens A-G Sharpston heeft een moedervennootschap een financiële prikkel om de werkgever die informatie te verschaffen, aangezien een financiële sanctie bij niet-nakoming van de informatieverplichting door de werkgever doorsijpelt naar de moedervennootschap (par. 54). 
Ook de toezeggingen van de werkgever in een sociaal plan kunnen leiden tot een resultaatsverbintenis tot herplaatsing. ${ }^{82}$ Daarnaast zie ik nog twee andere aanknopingspunten om een werknemer met voorrang te herplaatsen bij een ander concernonderdeel. Beide hebben betrekking op een bedrijfseconomisch ontslag. Het eerste aanknopingspunt betreft de in paragraaf 5.2 .1 besproken situatie dat het laten vervallen van arbeidsplaatsen uitgaat van de centrale leiding. In deze situatie is het mijns inziens redelijk dat indien bij een ander concernonderdeel een functie vrij is of komt, de door de concernreorganisatie getroffen werknemer voorrang heeft boven een externe kandidaat. ${ }^{83}$ Deze benadering past bij de gedachte van de wetgever dat concernbrede herplaatsing in wezen compensatie is voor de concernvriendelijke uitleg van artikel 3 Ontslagregeling. ${ }^{84}$ Het tweede aanknopingspunt betreft de situatie waarin het UWV (of de rechter) besluit dat rechtspersoonoverstijgend moet worden afgespiegeld. In paragraaf 5.2.3 gaf ik aan dat de Ontslagregeling hiervoor ruimte laat. Indien het in de rede ligt dat de werkgever over meerdere rechtspersonen afspiegelt, is het geen gekke gedachte dat de werkgever ook de herplaatsingsmogelijkheden bij die rechtspersonen moet benutten. ${ }^{85}$

\subsubsection{Plaatsmakersfuncties in het concern}

Het derde knelpunt is in hoeverre plaatsmakersfuncties bij andere concernonderdelen moeten worden betrokken bij de herplaatsing. Dat flexkrachten plaats moeten maken om vaste werknemers te herplaatsen is een nieuwe regel ten opzichte van het vóór de Wwz geldende recht. De regel kan worden afgeleid uit de doelstelling van de Wwz om 'doorgeschoten flex' terug te dringen. ${ }^{86}$ Op grond van artikel 7:671a lid 5 BW verleent het UWV slechts toestemming om de arbeidsovereenkomst op te zeggen op de a-grond als eerst afscheid is genomen van flexkrachten die werkzaam zijn in de arbeidsplaatsen die vervallen. De plaatsmakersbepaling bij herplaatsing sluit hierop aan. Op dit punt heeft de wetgever dus wel een wijziging ten opzichte van het oude recht beoogd. De vraag is in hoeverre deze wijziging kan worden toegepast op concernverhoudingen. Het uitgangspunt lijkt te zijn dat de werkgever de plaatsmakersfuncties bij andere concernonderdelen dient te betrekken bij de herplaatsing. Zo concludeerde de plaatsvervangend P-G in navolging van het hof dat deze functies, voor zover het buitenlandse arbeidsrecht die kent, bij de herplaatsing moeten worden betrokken (paragraaf 2.26 en

82 Beleidsregels Ontslagtaak UWV 2015, hfdst. 20, par. 4c; Ktr. Utrecht 21 december 2016, ECLI:NL:RBMNE:2016:6916, JAR 2017/44; Ktr. Maastricht 29 mei 2017, ECLI:NL:RBLIM: 2017:4850, AR Updates 2017-0690.

83 In gelijke zin Ktr. Amsterdam 29 november 2018, ECLI:NL:RBAMS:2018:8549, AR Updates 2018-1419.

84 Toelichting Ontslagregeling, p. 12.

85 In gelijke zin RDA Dordrecht 10 mei 1993, JAR 1993/209; vgl. Veerkamp 2018, par. 3.2.6.

86 Onder het oude recht gold of redelijkerwijs van de werkgever verlangd kon worden dat hij de flexkracht verving door een boventallige werknemer; Beleidsregels Ontslagtaak UWV 2015, hfdst. 20, par. 4b; De Graaf 2016, p. 19. 
2.48-2.50). ${ }^{87}$ Hoe ver de werkgever hierin moet gaan, moet blijkens de Shellbeschikking worden opgelost via de redelijkheidsnorm. Mijns inziens is het niet redelijk om van een concernonderdeel te eisen dat hij flexkrachten ontslaat om werknemers van andere concernonderdelen te herplaatsen. ${ }^{88}$ Ten eerste lopen werkgevers in internationale concerns aan tegen internationaal privaatrechtelijke beperkingen. Op flexkrachten van buitenlandse concernonderdelen is normaal gesproken niet het Nederlandse ontslagrecht van toepassing. ${ }^{89}$ Het is geen gegeven dat het lokale ontslagrecht toestaat dat flexkrachten worden ontslagen om plaats te maken voor andere werknemers. Ten tweede stellen Olivier en Wiewel naar mijn mening terecht dat toepassing van de plaatsmakersbepaling op flexkrachten in concerns tot een te grote onzekerheid over hun positie leidt. Een concernvennootschap kan bij de inschatting van de benodigde flexibele arbeidskrachten niet goed inspelen op eventuele boventalligheid elders in het concern. ${ }^{90}$ De redelijkheidsnorm laat ruimte om de belangen van flexkrachten van andere concernonderdelen mee te wegen. Onder het oude recht kon het UWV namelijk ook rekening houden met andere belangen dan de belangen van de werkgever en de met ontslag bedreigde werknemer. ${ }^{91}$

\section{Ter afsluiting: status quo van het concern in het ontslagrecht na Shell}

De integratie van het concern in het ontslagrecht is niet uniform. In deze annotatie kwam aan bod dat voor de toepassing van de h-grond het concern als de juridische relevante arbeidsorganisatie kan worden beschouwd, terwijl dit voor de agrond slechts gebeurt indien de bedrijfseconomische omstandigheden in het concern de noodzaak voor ontslag ondersteunen. Ook bleek dat bij herplaatsing het hele concern wordt betrokken, terwijl bij afspiegeling alleen onder bepaalde omstandigheden over rechtspersonen wordt gekeken. Zo zijn er meer voorbeelden. Deze gefragmenteerde benadering is op zich goed te verklaren. De betekenis van het concern voor de toepassing van een arbeidsrechtelijke bepaling hangt sterk af van de werking van en de ratio achter die bepaling. Het is niet vreemd dat het concern niet in alle bepalingen dezelfde betekenis toekomt: daarvoor verschillen de bepalingen te veel. Het komt steeds aan op een op de specifieke bepaling toegesneden redelijkheidstoets. In de Shell-beschikking benadrukt de Hoge Raad dit uitgangspunt voor zowel artikel 3 als artikel 9 Ontslagregeling. Zo beschouwd, past de Shell-beschikking goed in het systeem van de Ontslagregeling: het integreren van het concern vergt maatwerk. 2016:2820, AR Updates 2016-0613. Het argument van Laagland \& Lintsen (2016, p. 9), dat de toelichting ruimte laat om concernbrede herplaatsing niet te betrekken op plaatsmakersfuncties, vindt (vooralsnog) geen navolging.

91 Beleidsregels ontslagtaak UWV 2015, hfdst. 20, inleiding. 
Daarmee is de kous niet af. Dat de integratie gefragmenteerd is, wil niet zeggen dat zij niet kan stoelen op een duidelijke visie op het concern. Die visie ontbreekt. Voor een aantal bepalingen, zoals artikelen 3 en 14 Ontslagregeling, maken de wet(sgeschiedenis) of de beleidsregels van het UWV redelijk duidelijk of en onder welke omstandigheden de concernband van belang is. Voor andere bepalingen geldt dit niet. Herplaatsing is een prominent voorbeeld: de wetgever maakt duidelijk dat het concern betekenis toekomt, maar welke betekenis dat is en waar die betekenis van afhangt, wordt niet geconcretiseerd. Ook de Hoge Raad geeft geen aanwijzingen. Werkgevers en werknemers die deel uitmaken van een concern weten hierdoor niet waar zij aan toe zijn. Het verdient aanbeveling dat de wetgever, de rechtspraak en het UWV inzichtelijker maken en op elkaar afstemmen of, waarom en onder welke omstandigheden het concern bij de toepassing van een arbeidsrechtelijke bepaling een bepaalde betekenis toekomt. Ter inspiratie heb ik in deze annotatie een aantal van dergelijke gezichtspunten geschetst voor het bepalen van de reikwijdte van het herplaatsingsvereiste in concernverband. Daarbij bleek dat het tot op zekere hoogte tevens mogelijk is om de aanknopingspunten voor het concern in de artikelen 3 en 14 Ontslagregeling analoog toe te passen op de herplaatsingstoets. Ook het streven naar een dergelijke samenhang tussen de verschillende bepalingen verdient aanbeveling. Een meer uniforme benadering van het concern verhoogt de rechtszekerheid en vergemakkelijkt het leveren van maatwerk voor werknemers en concerns. 